\title{
Trousseau's sign at the emergency department
}

\author{
Bas C T van Bussel, Richard P Koopmans
}

Department of Internal Medicine, Maastricht University Medical Centre, Maastricht, The Netherlands

\section{Correspondence to} Dr Bas C T van Bussel, bas.van.bussel@mumc.nl

Accepted 19 July 2016

CrossMark

To cite: van Bussel BCT, Koopmans RP. BMJ Case Rep Published online:

[please include Day Month

Year] doi:10.1136/bcr-2016216270

\section{DESCRIPTION}

A 83-year-old woman presented with malaise, diarrhoea and cramps and tingling in arms and legs. Her medical history noted hypertension, hypercholesterolaemia, arthrosis of her knee and treatment of an upper airway tract infection with antibiotics 1 month ago.

Physical examination revealed a clear Trousseau's sign (video 1), which is a carpopedal spasm induced by ischaemia through inflation of a sphygmomanometer cuff to a suprasystolic blood pressure. Trousseau's sign emerged at $25 \mathrm{~s}$ after the start of cuff inflation, with a maximal spasm at $60 \mathrm{~s}$. Its reported sensitivity and specificity for hypocalcaemia are 94\% and 99\%, respectively. ${ }^{1}$ Indeed, her total calcium level was $4.8 \mathrm{mg}$ per decilitre (normal range, 8.4-10.2), and her free calcium level was $1.32 \mathrm{mEq}$ per litre (normal range 2.20-2.60). Vitamin D was deficient at $8 \mathrm{ng}$ per millilitre (normal range $>36$ ) and parathyroid hormone level was slightly raised to $89 \mathrm{pg}$ per millilitre (normal range 12-62).

In contrast, to a previous reported video case, Chvostek's sign was not clinically present. ${ }^{1}$ This may be explained by different causes of hypocalcaemia between both cases (ie, vitamin D deficiency vs postsurgically acquired hypoparathyroidism) or by the fact the Chvostek's sign is absent in about one-third of patients with hypocalcaemia. ${ }^{1}$

Her cramps and tingling resolved with intravenous suppletion of calcium gluconate. She started oral vitamin $\mathrm{D}$ and calcium suppletion.

In addition, she had low magnesium and potassium levels, acute kidney injury and faeces analysis tested positive for clostridium difficile. She was treated with intravenous electrolyte substitution,

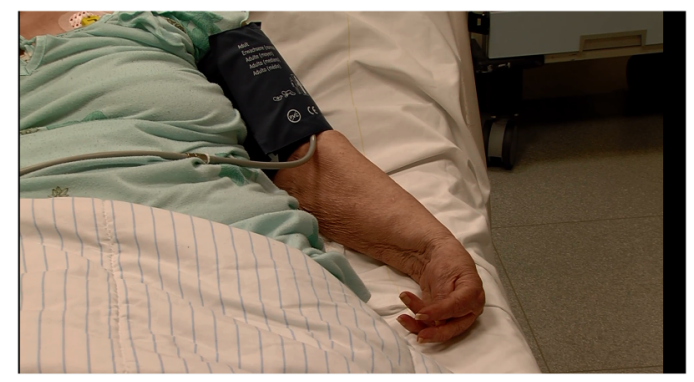

Video 1 Trousseau's sign.

fluids and metronidazole. During admission she developed melaena and gastroscopy showed a gastric tumour. She did not want further evaluation and was discharged with appropriate care.

\section{Learning points}

- This video is an excellent image of Trousseau's sign.

- Trousseau's sign is caused by hypocalcaemia.

Competing interests None declared.

Patient consent Obtained.

Provenance and peer review Not commissioned; externally peer reviewed.

\section{REFERENCE}

1 Jesus JE, Landry A. Images in clinical medicine. Chvostek's and Trousseau's signs. N Engl J Med 2012;367:e15.

Copyright 2016 BMJ Publishing Group. All rights reserved. For permission to reuse any of this content visit http://group.bmj.com/group/rights-licensing/permissions.

BMJ Case Report Fellows may re-use this article for personal use and teaching without any further permission.

Become a Fellow of BMJ Case Reports today and you can:

- Submit as many cases as you like

- Enjoy fast sympathetic peer review and rapid publication of accepted articles

- Access all the published articles

- Re-use any of the published material for personal use and teaching without further permission

For information on Institutional Fellowships contact consortiasales@bmjgroup.com

Visit casereports.bmj.com for more articles like this and to become a Fellow 